\title{
Ultrastructural data on the spore of Myxobolus maculatus n. sp. (phylum Myxozoa), parasite from the Amazonian fish Metynnis maculatus (Teleostei)
}

\author{
G. Casal ${ }^{1,2}$, E. Matos ${ }^{3}$, C. Azevedo ${ }^{2,4, *}$ \\ ${ }^{1}$ Department of Biological Sciences, High Institute of Health Sciences, 4580 Paredes, Portugal \\ ${ }^{2}$ CIIMAR - Centre for Marine and Environmental Research, University of Oporto, 4150-180 Porto, Portugal \\ ${ }^{3}$ Laboratory of Animal Biology, Faculty of Agricultural Sciences, Belém, Brazil \\ ${ }^{4}$ Department of Cell Biology, Institute of Biomedical Sciences, University of Oporto, 4099-003 Porto, Portugal
}

\begin{abstract}
Light and electron microscopy studies of a myxosporean, parasitic in the intertubular interstitial tissue of the kidney of the freshwater teleost fish Metynnis maculatus Kner, 1860 (Characidae) from the lower Amazon River (Brazil), are described. We observed polysporic histozoic plasmodia delimited by a double membrane and with several pinocytic channels and containing several life cycle stages, including mature spores. The spore body was of pyriform shape and was $21.0 \mu \mathrm{m}$ long, $8.9 \mu \mathrm{m}$ wide and $7.5 \mu \mathrm{m}$ thick. Elongated-pyriform polar capsules were of equal size $(12.7 \times$ $3.2 \mu \mathrm{m}$ ) and contained a polar filament with 14 or 15 coils. The spore features fit those of the genus Myxobolus. Densification of the capsular primordium matrix, which increased in density from the inner core outwards, differentiating at the periphery into small microfilaments measuring $45 \mathrm{~nm}$ each, and tubuli arranged in aggregates and dispersed within the capsular matrix of the mature spores, are described. Based on the morphological differences and specificity of the host, we propose the creation of a new species named Myxobolus maculatus n. sp.
\end{abstract}

KEY WORDS: Ultrastructure $\cdot$ Parasite $\cdot$ Myxosporidian $\cdot$ Myxobolus maculatus $\cdot$ Amazonian fish Resale or republication not permitted without written consent of the publisher

\section{INTRODUCTION}

The genus Myxobolus Bütschli, 1882 (family Myxobolidae), is the largest myxosporean group, and its members are important pathogens of freshwater and marine fishes in several geographical areas. The morphology and ultrastructure of myxosporean species have been widely studied (Landsberg \& Lom 1991, Lom \& Dyková 1992). However, in Brazilian host species, few have been described and, with the exception of 1 ultrastructural study (Casal et al. 1996), only light microscopy descrip-

\section{${ }^{*}$ Corresponding author.}

Present address: Department of Cell Biology, Institute of Biomedical Sciences, University of Oporto, Lg. Professor Abel Salazar no. 2, 4099-003 Porto, Portugal.

E-mail: azevedoc@icbas.up.pt tions are available (Walliker 1969, Kent \& Hoffman 1984, Molnár \& Békési 1993, Gioia \& Cordeiro 1996, Molnár et al. 1998). In this paper we present light and electron microscopical data of a new myxosporidian species, M. maculatus n. sp., found in the teleost fish, Metynnis maculatus collected from the Amazon River. Some peculiar ultrastructural aspects of the structure of the plasmodium and developmental stages of the capsulogenesis are described and discussed.

\section{MATERIALS AND METHODS}

A parasite found in the kidney of the freshwater teleost Metynnis maculatus Kner, 1860 (family Characidae), known by the Brazilian common name 'pacú', was investigated. The specimens were collected peri- 
odically during the year 2000 from the estuarine region of the Amazon River, near Belém, Brazil. Plasmodia with mature spores were examined in fresh mounts with a light microscope equipped with Nomarski differential interference-contrast optics. For TEM, small parasitized fragments were fixed in $3 \%$ glutaraldehyde in $0.2 \mathrm{M}$ sodium cacodylate buffer $(\mathrm{pH}=7.4)$ at $4^{\circ} \mathrm{C}$ for $6 \mathrm{~h}$, then washed with the same buffer overnight and post-fixed in $2 \% \mathrm{OsO}_{4}$ buffered with $0.2 \mathrm{M}$ sodium cacodylate for $2 \mathrm{~h}$ at the same temperature. The fragments were dehydrated in an ascending ethanol and propylene oxide series and then embedded in Epon. Semithin sections were stained with methylene blue and photographed under the light microscope (DIC). Ultrathin sections, cut with a diamond knife, were stained with both aqueous uranyl acetate and lead citrate and observed in a JEOL 100CXII TEM operated at $60 \mathrm{Kv}$.

\section{RESULTS}

Several foci of infection, plasmodia of approximately $150 \mu \mathrm{m}$ diameter localized in the intertubular interstitial tissue of the kidney, were observed. The infected kidney presented cellular and nuclear hypertrophy accompanied by morphological changes, such as organelle disorganization and cytoplasm vacuolization (Fig. 1). Sporogenic stages released into the renal interstitium due to basement membrane rupture were frequently observed (Fig. 7). Asynchronous histozoic plasmodia containing several life-cycle developmental stages of the parasite (generative cells, sporogenic stages and mature spores) were observed (Figs. 1 \& 3). The plasmodia were delimited by 2 membranes, the innermost being continuous with a distinct zone of pinocytic channels (Fig. 3: inset). The external plasmodial membrane was slightly separated from the endothelial cells and possessed a sinuous outline with some papillary buds (Fig. 3).

\section{Sporogenesis}

Pansporoblast formation followed the well-known pattern of a sporogenic cell developing into 2 spores within a pericyte. Morphogenesis of capsulogenic cells corresponded to that of most myxosporeans, yet some specific features were found. Capsulogenesis began with a club-shaped formation that posteriorly changed to a globular structure, the capsular primordium, which extended into an external tube (Figs. 4 \& 6). Early in development, the distal end of the external tube was located below the future discharge channel leading through the shell valve, and was sealed by an electron- dense structure (Fig. 6). Inside the capsular primordium, before the inversion of the external tube, the matrix was composed of a fine dense granular structure. This was organized in concentric layers that gradually densified from the inner core outwards, being differentiated into fine microfilaments at the periphery. These microfilaments measured about $45 \pm 5 \mathrm{~nm}$ in diameter and were arranged in a continuous row (Figs. 4 \& 5). Simultaneously, the polar filament differentiated at the external tubule and then invaginated and coiled inside the matrix (Fig. 7). In mature spores, the matrix became denser and numerous electrolucent aggregates of tubuli, arranged in bundles around the polar filament, were observed (Fig. 8).

\section{Spore characteristics}

Fresh mature spores were of pyriform shape, tapering anteriorly to a slightly knob-like end, and measured $\sim 21.0 \times \sim 8.9 \mu \mathrm{m}$ in anterior view (Figs. $2 \& 9$ ). The spore wall was thin and smooth, comprising 2 equal valves joined by a sutural ridge. No mucus envelope was observed at the surface of the spore (Fig. 2). Internally, 2 capsulogenic cells, located side by side, contained prominent polar capsules (PCs) of elongated pyriform shape and equal size, measuring $\sim 12.7 \times$ $\sim 3.2 \mu \mathrm{m}$ (Figs. $2 \& 9$ ). The PCs occupied approximately two-thirds of the total spore length. Inside the PCs, a polar filament displayed 14 or 15 coils perpendicular or slightly oblique to the longitudinal axis (Figs. 2 \& 7). No intercapsular appendix was present (Fig. 2). At the posterior pole of the spore, a binucleated sporoplasm contained numerous electron-dense vesicles, sporoplasmosomes, glycogen granules and an extensive system of rough endoplasmic reticulum cisternae (Fig. 7). Fresh mature spores and ultrathin sections demonstrated the existence of a large iodinophilous vacuole in the sporogenic cell measuring approximately $4.5 \mu \mathrm{m}$ in diameter (Fig. 2).

\section{Diagnosis}

Host: teleost fish, Metynnis maculatus Kner, 1860 (family Characidae).

Locality: estuarine region of the Amazon river (011' $\left.30^{\prime} \mathrm{S}, 47^{\circ} 18^{\prime} 54^{\prime \prime} \mathrm{W}\right)$ near Belém, Brazil.

Site of infection: spores were located in the kidney. Prevalence and intensity: 12 out of $30(40 \%)$.

Fresh spore measurements $(n=40)$ : length $=21.0(19.7$ to 23.0) $\mu \mathrm{m}$, width $=8.9$ (7.9 to 9.5) $\mu \mathrm{m}$, thickness $=7.5$ (7.2 to 7.9$) \mu m_{\text {; }}$ polar capsules: length $=12.7$ (11.8 to 13.8) $\mu \mathrm{m}$, width $=3.2$ (3.0 to 3.6) $\mu \mathrm{m}_{\text {; number of polar }}$ filament turns $=14$ to 15 . 


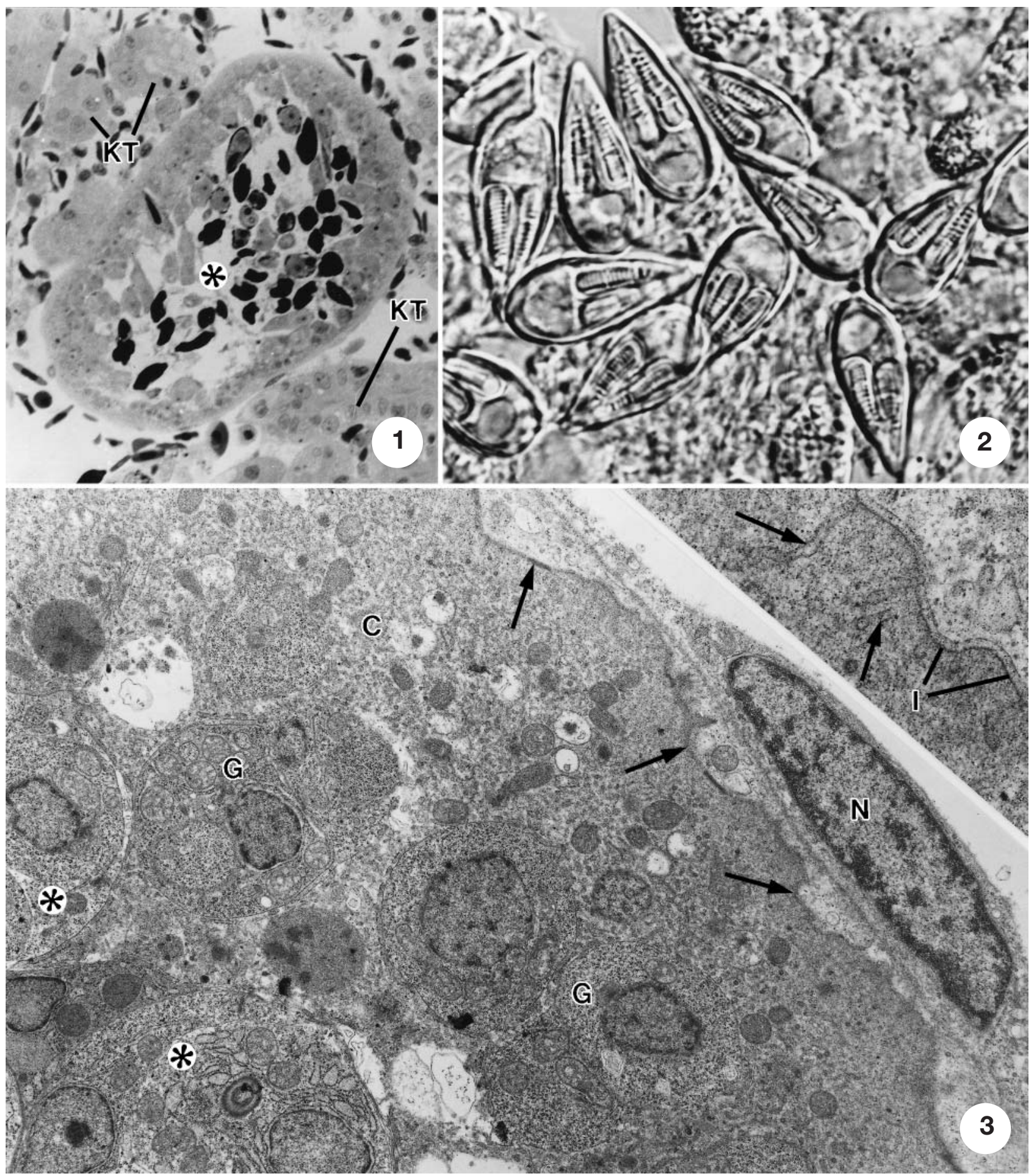

Figs. 1-3. Myxobolus maculatus n. sp. Life cycle stages of the parasite in the kidney of Metynnis maculatus. Fig. 1. Semithin section showing plasmodium (*) in the intertubular intertitial tissue of the kidney (KT). Fig. 2. Fresh mature spores observed with differential interference-contrast (Nomarski). Fig. 3. Plasmodium delimited by double membrane (arrows) showing much cytoplasmatic degradation $(\mathrm{C})$ and different life cycle stages, such as generative cells (G) and sporogenic stages (*); Outside the plasmodium an endothelial cell nucleus $(\mathrm{N})$ is visible. Inset $(\times 8800)$ shows detail of the plasmodium wall with membranes, the innermost (I) of which is in direct contact with the pinocytic channels (arrows). (Scale bars: $1=\times 500 ; 2=\times 1525 ; 3=\times 32000$ ) 

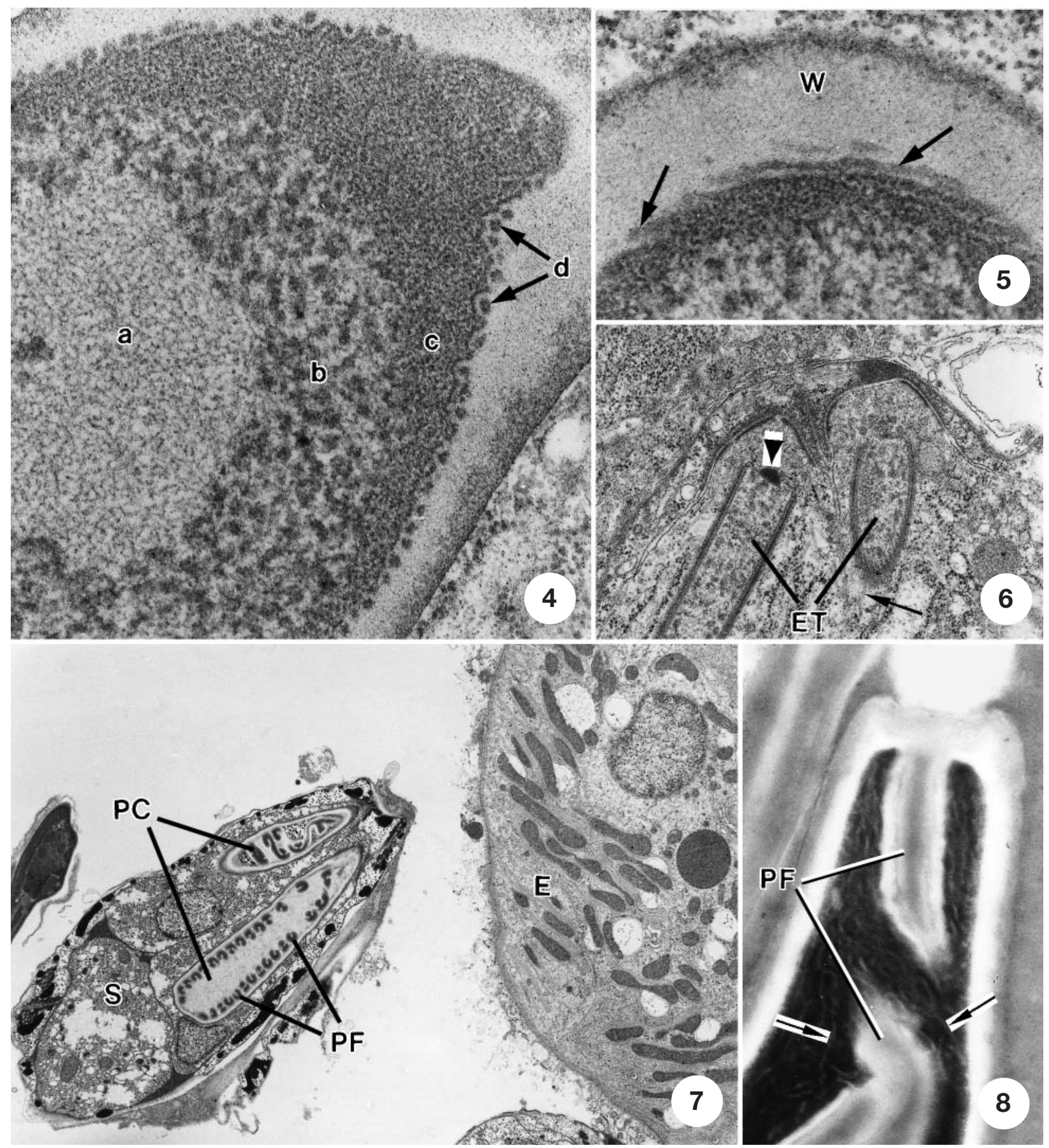

Figs. 4-8. Myxobolus maculatus n. sp. Life cycle stages of the parasite in the kidney of Metynnis maculatus. Fig. 4. Transverse section of a capsular primordium showing the matrix with different degrees of densification $(a, b, c)$, and the periphery differentiated into fine microfilaments (d). Fig. 5. Detail of a capsular primordium in tangential section showing some microfilaments (arrows) near the capsular primordium wall (W). Fig. 6. Anterior pole of 2 capsulogenic cells, each with an external tubule (ET) surrounded by microtubules (arrow) and sealed by an electron-dense structure (arrowhead). Fig. 7. Immature spore localized in the interstitial tissue showing the polar capsules (PC) with polar filaments (PF) coiled inside, sporoplasm (S) and epithelial cells (E) of the uninfected kidney tubule. Fig. 8. Detail of a densified mature polar capsule, showing numerous tubuli organized into aggregates (arrows) and associated with the polar filament (PF). (Scale bars: $4=\times 40000 ; 5=\times 50400 ; 6=\times 20800 ; 7=\times 4480$; $8=\times 40000)$ 
Specimens deposited: slides with holotype were deposited in the International Protozoan Type Slides Collection at the Smithsonian Institution, Washington, DC 20560, USA (USNM \#1002151) and in the collection of the senior author.

Etymology: the specific name is derived from the name of the host species ('maculatus').

\section{DISCUSSION}

The mature spores obtained from Metynnis maculatus revealed morphological similarities to those of the genus Myxobolus Bütschli, 1882. Comparison of the plasmodium wall and sporogenesis of the cycle life stages of this species to those of other Myxobolus spp. also revealed morphologic and ultrastructural similarities (Lom \& Puytorac 1965, Desser \& Paterson 1978, Current et al. 1979, Lom \& Dyková 1992).

The plasmodial wall presented an organization typical for histozoic Myxobolus species, with a double membrane and pinocytic channels region extending

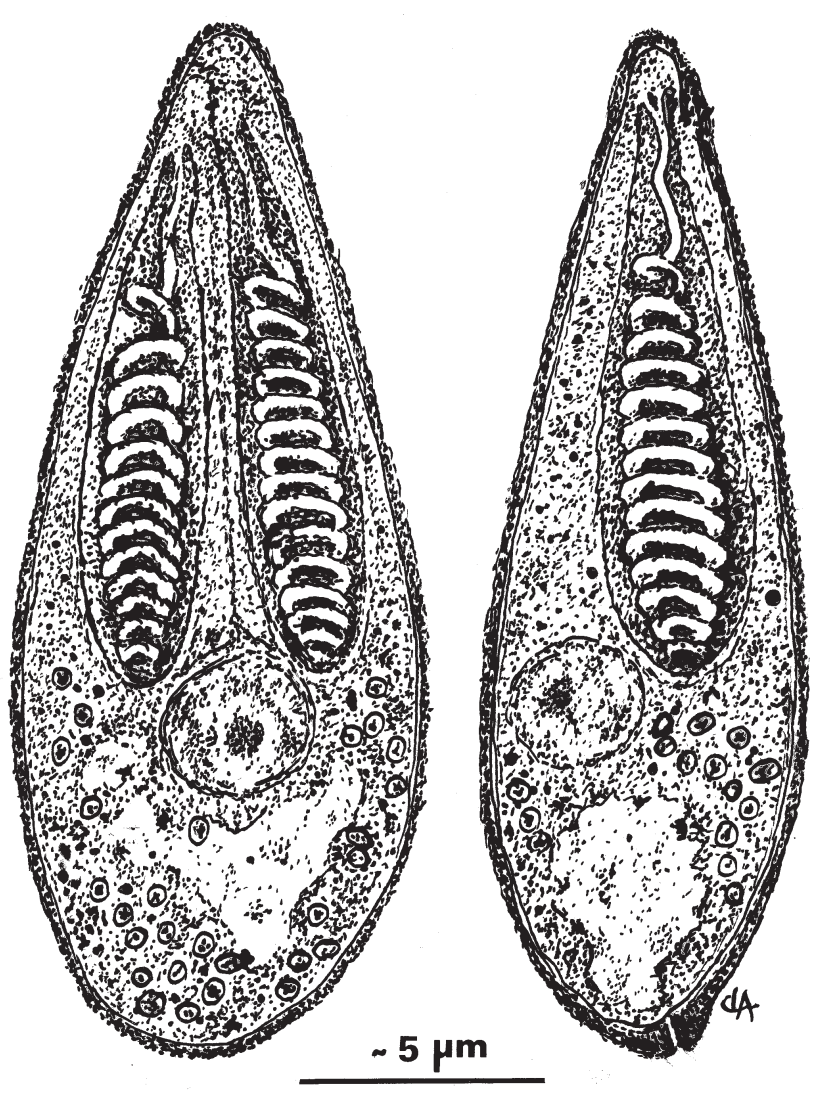

Fig. 9. Myxobolus maculatus n. sp. Schematic drawings of morphology of a spore in anterior (left) and lateral (right) view as described in 'Results' and illustrated in Figs. 2 \& 7 into the ectoplasmic zone of the plasmodium (Desser \& Paterson 1978, Current et al. 1979). All Myxobolus species give rise to histozoic plasmodia, except for one species, M. conei, that is found in the lumen of bile ducts in the liver of Pseudocaranx dentex (Lom \& Dyková 1994). Usually, myxosporidian species that parasitize renal tubules are coelozoic and do not belong to the genus Myxobolus (Lom 1969, Desser et al. 1983, Lom \& Dyková 1985). In the present work we describe a new histozoic species found in the intertubular interstitial tissue of the kidney. Unfortunately, studies of other Myxobolus species reported to parasitize the same organ make but few references to the ultrastructural morphology of the plasmodia (Lom \& Dyková 1992).

The ultrastructural process of capsulogenesis differentiation has been well documented in several myxosporidian genera (Lom \& Puytorac 1965, Lom 1969, Current et al. 1979, Desser et al. 1983). The structure of the capsular matrix, i.e. immature spores formed by concentric layers and differentiated at the periphery into only 1 row of microfilaments, presents some differences with the one species (Thelohanellus nikolskii) described by Desser et al. (1983), who described a microfilamentous girdle surrounding the capsular matrix and speculated that it was probably connected with the contractions required for external tubule inversion (Desser et al. 1983). In mature spores, bundles of tubuli in the capsular matrix have already been referred to in some genera, such as Sphaeromyxa (Lom 1969) and Henneguya (Rocha et al. 1992), but never in Myxobolus species. This suggests that these tubules probably have an important function in the extrusion of the polar filament.

The pathological changes in the renal tissue such as degeneration and vacuolisation of the renal epithelial cells associated with the presence of the parasites Sphaerospora spp. (Lom \& Dyková 1985), are similar to those observed in $M$. maculatus in the present study.

There are at least 444 species belonging to this genus (Landsberg \& Lom 1991), and most of the early species descriptions are vague, presenting only line drawings of the spores. At present there are 16 Myxobolus species described in Amazonian fishes (Walliker 1969, Kent \& Hoffman 1984, Molnár \& Békési 1993, Casal et al. 1996, Gioia \& Cordeiro 1996, Molnár et al. 1998). The Brazilian species-M. cunhai (Penido 1927), microspores of $M$. serrasalmi (Walliker 1969) and M. braziliensis (Casal et al. 1996) - all have a similar body shape, but are smaller than the species described here. Only $M$. inaequus (Kent \& Hoffman 1984 ) is of similar size, however its oval, unequal polar capsules and its infestation of other host species all exclude the possibility of it being the same species as that described herein. 
Among Myxobolus spp. from other geographic localities, some present a similar body shape, such as M. koi and M. funduli (Kudo 1919), M. procerus (Kudo 1934), M. neurophilus and M. scleroperca (Guilford 1963), M. punctatus (Ray-Chaudhuri \& Chakravarty 1970), $M$. pharyngeus (Parker et al. 1971), and M. maruliensis (Sarkar et al. 1985), but all are smaller in size. Comparison of the spores of 3 species-M. magnasherus (Cone \& Anderson 1977), M. ovoidalis (Fantham 1930) and M. squamaphilus (Molnár 1997) — revealed similar sizes to that in our study, but all were oval in shape compared to the pyriform shape in our study.

Comparison of our results with those for other Мyхоbolus species revealed some significant differences, mainly in size and body shape of the spores as well as host-specificity and ultrastructural details, suggesting that this parasite ( $M$. maculatus) is a new species.

Acknowledgements. This work was partially supported by a grant from the Engenheiro António Almeida Foundation, Porto, Portugal. We would like to thank the iconographic work of Mr. João Carvalheiro. The electron microscopy assistance provided by Mrs. Laura Corral is gratefully acknowledged.

\section{LITERATURE CITED}

Casal G, Matos E, Azevedo C (1996) Ultrastructural data on the life cycle stages of Myxobolus braziliensis n. sp., parasite of an Amazonian fish. Eur J Protistol 32:123-127

Cone DK, Anderson RC (1977) Myxosporidian parasites of pumpkinseed (Lepomis gibbosus L.) from Ontario. J Parasitol 63:657-666

Current WL, Janovy J Jr, Knight SA (1979) Myxosoma funduli Kudo (Myxosporida) in Fundulus kansae: ultrastructure of the plasmodium wall and of sporogenesis. J Protozool 26:574-583

Desser SS, Paterson WB (1978) Ultrastructural and cytochemical observations on sporogenesis of Myxobolus sp. (Myxosporida: Myxobolidae) from the common shiner Notropis cornutus. J Protozool 25:314-326

Desser SS, Molnar K, Weller I (1983) Ultrastructure of sporogenesis of Thelohanellus nikolskii Akhmerov, 1955 (Myxozoa: Myxosporea) from the common carp, Cyprinus carpio. J Parasitol 69:504-518

Fantham HB (1930) Some parasitic protozoa found in South Africa. S Afr J Sci 27:376-390

Gioia I, Cordeiro NS (1996) Brazilian myxosporidians' checklist (Myxozoa). Acta Protozool 35:137-149

Guilford HG (1963) New species of Myxosporidia found in percid fishes from Green Bay (Lake Michigan). J Parasitol 49:474-478

Kent ML, Hoffman GL (1984) Two new species of Myxozoa, Myxobolus inaequus sp. n. and Henneguya theca sp. n.

Editorial responsibility: Wolfgang Körting,

Hannover, Germany from the brain of a South American knife fish, Eigemannia virescens (V.). J Protozool 31:91-94

Kudo RR (1919) Studies on Myxosporidia. III. Biol Monogr 5:241-503

Kudo RR (1934) Studies on some protozoan parasites of fishes of Illinois. III. Biol Monogr 13:1-41

Landsberg JH, Lom J (1991) Taxonomy of the genera of the Myxobolus/Myxosoma group (Myxobolidae: Myxosporea): current listing of species and revision of synonyms. Syst Parasitol 18:165-186

Lom J (1969) Notes on the ultrastructure and sporoblast development in fish parasitizing myxosporidian of the genus Sphaeromyxa. Z Zellforsch 97:416-437

Lom J, Dyková I (1985) Hoferellus cyprini Doflein, 1898 from carp kidney: a well established myxosporean species or a sequence in the developmental cycle of Sphaerospora renicola Dyková and Lom, 1982? Protistologica 21:195-206

Lom J, Dyková I (1992) Myxosporidia (phylum Myxozoa). In: Lom J, Dyková I (eds) Protozoan parasites of fishes. Developments in aquaculture and fisheries science, Vol 26. Elsevier, Amsterdam, p 159-235

Lom J, Dyková I (1994) Studies on protozoan parasites of Australian fishes. III. Species of the genus Myxobolus Bütschli, 1882. Eur J Protistol 30:431-439

Lom J, Puytorac P (1965) Studies on the myxosporidian ultrastructure and polar capsule development. Protistologica 1:53-65

Molnár K (1997) Myxobolus squamaphilus sp. n. (Myxozoa: Myxosporea), a common parasite of the scales of bream (Abramis brama L.). Acta Protozoologica 36:221-226

Molnár K, Békési L (1993) Description of a new Myxobolus species, M. colossomatis n. sp. from the teleost Colossoma macropomum of the Amazon River basin. J Appl Ichthyol 9:57-63

Molnár K, Ranzani-Paiva MJ, Eiras JC, Rodrigues EL (1998) Myxobolus macroplasmodialis sp. n. (Myxozoa: Myxosporea), a parasite of the abdominal cavity of the characid teleost, Salminus maxillosus. Acta Protozoologica 37: $241-245$

Parker JD, Spall RD, Warner MC (1971) Two new Myxosporida, Henneguya gambusi sp. n. and Myxosoma pharyngeus sp. n., in the mosquitofish, Gambusia affinis (Baird and Girard). J Parasitol 57:1297-1301

Penido JCN (1927) Quelques nouvelles myxosporidies parasites des poissons d'eau douce du Brésil. CR Séances Soc Biol 97:850-852

Ray-Chaudhuri S, Chakravarty MM (1970) Studies on Myxosporidia (Protozoa, Sporozoa) from the food fishes of Bengal. I. Three new species from Ophicephalus punctatus Bloch. Acta Protozool 8:167-175

Rocha E, Matos E, Azevedo C (1992) Henneguya amazonica n. sp. (Myxozoa, Myxobolidae), parasitizing the gills of Crenicichla lepidota Heckel, 1840 (Teleostei, Cichlidae) from Amazon river. Eur J Protistol 28:273-278

Sarkar NK, Mazumder SK, Pramanik A (1985) Observations on 4 new species of Myxosporidia (Myxozoa) from channid (ophicephalid) fishes of west Bengal, India. Arch Protistenkd 130:289-296

Walliker D (1969) Myxosporidea of some Brazilian freshwater fishes. J Parasitol 55:942-948

Submitted: July 15, 2001; Accepted: February 18, 2002

Proofs received from author(s): August 9, 2002 